Teichert, C. 1937: A new Ordovician fauna from Washington Land, North Greenland. Meddr Gronland 119,1, 65 pp.

Troedsson, G. T. 1928: On the Middle and Upper Ordovician faunas of northern Greenland. Part II. Meddr Gr申nland 72(1),1, 197 pp.

Twenhofel, W. H. 1928: Geology of Anticosti Island. Mem. geol. Surv. Can. 154, 481 pp.

\title{
Reconnaissance of the Thule Group and underlying basement rocks between Inglefield Bredning and Melville Bugt, western North Greenland
}

\section{Peter R. Dawes}

Field work was undertaken in August and September using boat transport locally hired from Avatak Henson of Moriussaq and Innuterssuak Uvdloriak of Siorapaluk. Travel from Thule Air Base to headquarters at Thule at the end of July was by U.S. Coastguard icebreaker Westwind. The work was a southerly continuation of the coastal programme started in 1971 (Dawes, 1972). About $1000 \mathrm{~km}$ of coastline was traversed including Herbert $\varnothing$, Northumberland $\varnothing$, Haklyut $\varnothing$, Saunders $\varnothing$ and Wolstenholme $\emptyset$. Heavy ice conditions in mid-September prevented penetration into the fjords between Kap York and Savigsivik.

\section{Crystalline basement}

Two major rock complexes compose the basement south of Inglefield Bredning (fig. 9). The greater part of the region is made up of a gneiss-schist-granite complex which is bordered on the south by a suite of igneous rocks referred to here as the Kap York meta-igneous complex.

Gneiss-schist-granite complex. Severely deformed grey to pink, biotite and hornblendebearing veined gneisses of mainly granodioritic composition form the dominant rock types. These gneisses are commonly melanocratic and characterised by reddish brown weathering. Numerous amphibolite layers, schlieren and concordant quartzo-feldspathic veins and streaks produce transitions to banded and streaky gneisses. Local areas of porphyroblastic gneiss and foliated granitoid rocks were seen along the coast between Narssârssuk and Parker Snow Bugt and are probably comparable in type with the extensive area of 'porphyroblastic gray gneiss' described by Davies et al. (1963) near the Inland Ice south of Pitugfik Gletscher. A mass of medium-grained leucocratic granite on the north side of Pitugfik Gletscher lies in sharp contact with gneisses and amphibolites and is probably of intrusive origin.

Biotite-garnet schists, mica-chlorite-talc schists and quartz-mica schists form small concordant units in the gneiss terrain. Tracts of quartz-rich garnet gneiss in the interior of Olrik Fjord are probably of metasedimentary origin. 


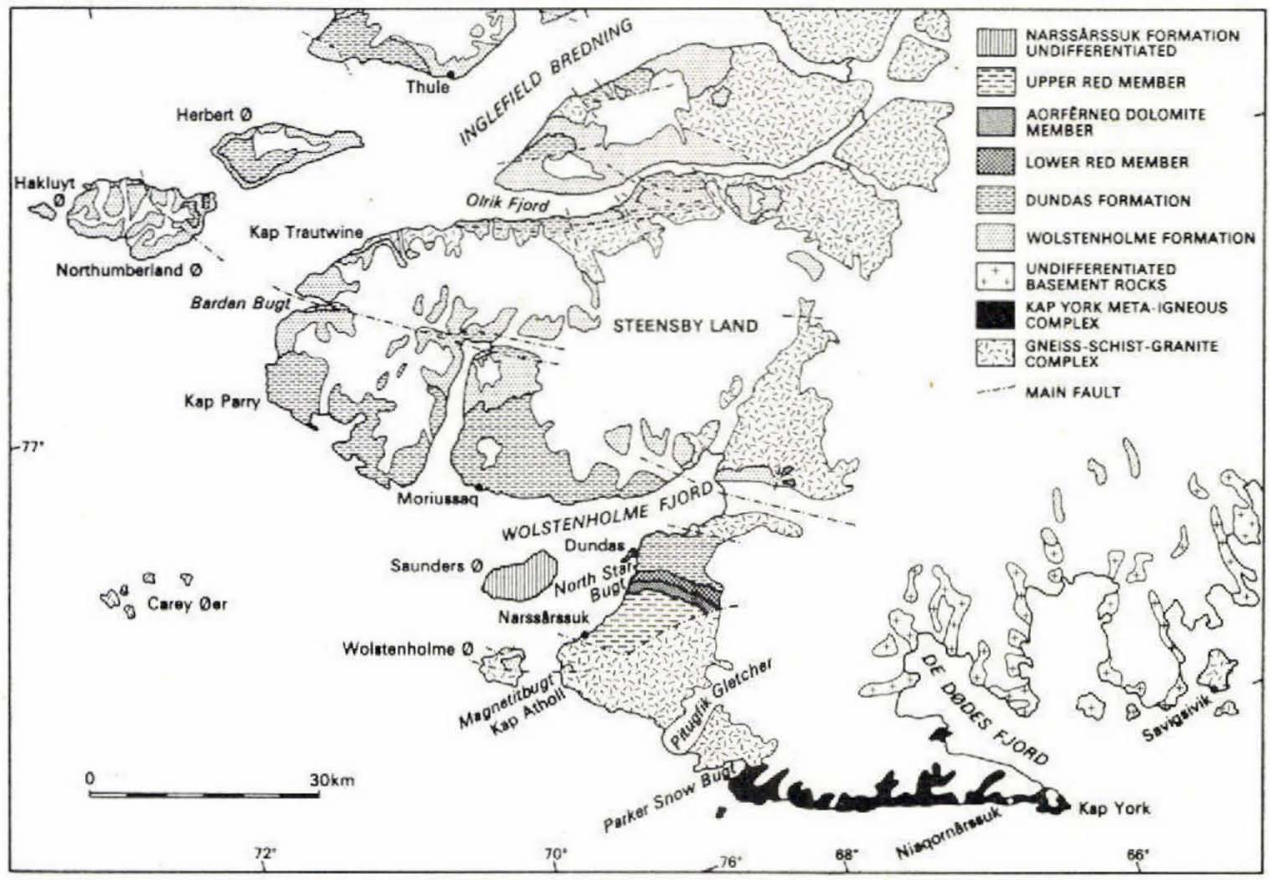

Fig. 9. Geology of the region between Inglefield Bredning and Melville Bugt, western North Greenland.

Basic and ultrabasic rocks occur in the gneisses as mostly discontinuous often fragmented concordant layers as well as smaller isolated masses, lenses and schlieren. Main rock types are dark grey to black, often rusty weathering amphibolites, hornblendebiotite schists with garnet and diopside, black to green hornblendites, as well as lighter coloured chlorite-amphibolite-talc schists. Agmatitic veining is common and in places mobility of gneiss material has produced discordant contact relationships. A large banded outcrop at Uvdle contains a conformable succession over $200 \mathrm{~m}$ thick of garnet-pyroxene bearing amphibolites and schists containing structures suggestive of a volcanic origin.

Following the main migmatisation, metamorphism and deformation of the complex, basic and acid rocks were emplaced as minor intrusions. The relationships between these rock types are evident in the coastal cliffs at Kap Trautwine where grey to pink, fine to medium-grained granite sheets contain disorientated enclaves of highly foliated gneiss and amphibolite which they traverse. These sheets are cut and dilated by a network of pegmatite dykes, sheets and more irregular masses. Discordant amphibolite dykes cut at least one generation of granitic sheets but pre-date the main phase of pegmatisation. These dykes are slightly folded and broken up. A green basic dyke on Wolstenholme $\varnothing$ cuts the gneisses but is truncated by the erosion surface at the base of the unmetamorphosed Thule Group. 
Kap York meta-igneous complex. This complex forms the entire coast from Parker Snow Bugt to Kap York and probably stretches eastwards into De Dødes Fjord. The rocks vary from dark grey to brown metagabbro and metadolerite to diorite and tonalite, into light coloured granodioritic and granitic rocks. There is a gradation in metamorphic character from the rocks with preserved ophitic textures to schistose rocks containing metamorphic biotite and garnet. Basic and acidic phases are distinct in some areas although gradational contacts suggest a certain amount of feldspathisation. Davies et al. (1963) mention bands of diorite up to $16 \mathrm{~m}$ wide containing large pink feldspar crystals. Around Niaqornârssuk a moderately to steeply inclined compositional banding parallel to schistosity was observed.

\section{Deformation, metamorphism and chronology}

Large scale isoclinal folds in gneiss and associated amphibolites are clearly seen in the steep fjord walls in the interior of Olrik Fjord. Small-scale, interference patterns suggest that there were at least two phases of isoclines. A series of more open folds is exposed along the coast between Kap Atholl and Pitugfik Gletscher.

Amphibole and biotite are deformed by the later isoclinal folds proving that early metamorphism reached at least amphibolite facies conditions. High-grade regional metamorphism is also thought to have prevailed during later deformation with the production of hornblende, biotite and garnet. Chlorite-mica-talc assemblages in basic and ultrabasic rocks are taken to represent late retrogressive metamorphism of low amphibolite or greenschist facies. The late granites and discordant amphibolites appear to post-date this retrogression.

The Kap York meta-igneous complex is a possible age equivalent of the late minor intrusions of the gneiss-schist-granite complex. Both post-date main periods of metamorphism and deformation. The boundaries of the Kap York meta-igneous complex were not located in 1974 but according to Davies et al. (1963) the meta-igneous rocks cut the surrounding gneisses with sharp contacts. Late deformation and metamorphism has affected both the late minor intrusions and the Kap York meta-igneous complex.

\section{Thule Group}

The Thule Group of unmetamorphosed late Precambrian sedimentary and volcanic rocks overlies the basement with profound unconformity. From estimates made in 1974 the composite thickness of this group is known to exceed $4 \mathrm{~km}$. Some notes on the three formations of the Thule Group, from the base up, follow.

The Wolstenholme Formation thickens markedly westwards towards the centre of the Thule basin. At the type locality on Wolstenholme $\emptyset$ the formation has a thickness of about $500 \mathrm{~m}$ (Davies et al., 1963). In the Herbert $\emptyset$ - Northumberland $\emptyset$ region a succession at least $2 \mathrm{~km}$ thick can be divided into four members: (a) a basal multicoloured member of mainly ferruginous sandstone and quartzite; (b) a white to pink member of massive quartzites; (c) a red to purple member of sandstone, shale and conglomerate; and (d) a buff to yellow member of sandstones, quartzites and quartzpebble conglomerates. Reddish brown, agate and xenolith-bearing volcanic rocks and 
thick dolerite sills occur in the lowest member. Ripple marks and cross-bedding are common and trace fossils were discovered in the uppermost member (Dawes \& Bromley, this report).

The Dundas Formation, a dark weathering, thin-bedded unit over $1 \mathrm{~km}$ thick, overlies the Wolstenholme Formation with a gradational contact. The base of the Dundas Formation consists of an alternation of shale and fine-grained sandstone; upwards these rocks are interbedded with calcareous shale and dolomite. In Steensby Land large areas show rusty weathering due to sulphide mineralisation (see below). The dolomites are grey to bluish grey, often with a yellow to brown and rusty weathering, and have a massive to platy lithology. In places the dolomites are stromatolitic and small stromatolitic reefs were noted. Dolerite sills are abundant in the Wolstenholme Fjord Steensby Land region but are absent in the formation in the northern part of the Thule basin, north of Inglefield Bredning. In southern Steensby Land at least 12 thick sills form a sill system that dominates the landscape.

The Narssârssuk Formation, at least $1 \mathrm{~km}$ of multicoloured, cyclic deposited dolomite, shale, sandstone and siltstone, was examined briefly. There are marked variations in the proportions of the different rock types composing the cycles and compressed and incomplete cycles are common. Irregular bedding surfaces with stromatolites and stylolite structures are frequent in the dolomites. The division into a Lower Red Member, the Aorfêrneq Dolomite Member (lacking red coloured siltstone units) and an Upper Red Member on the mainland forms a conformable uninterrupted succession. However, the seemingly uncomplicated shallow-dipping strata forming the steep cliffed coastline of Saunders $\emptyset$ contain normal fault displacements and a much thicker succession is exposed than hitherto envisaged. Correlation between Saunders $\varnothing$ and the mainland is difficult and the earlier correlation of the entire Saunders $\emptyset$ succession with the Upper Red Member of the mainland (Davies et al., 1963) is questioned.

\section{Structure, faulting and basic intrusion}

The Thule Group is flat-lying to shallow-dipping, preserved mainly in down-faulted blocks. Drag effect along main faults had resulted in some steeply inclined and folded sections particularly in the Dundas Formation. Movement along the faults has probably occurred at several times but the main late Precambrian movement post-dates the intrusion of at least some of the basic sills that cut the Wolstenholme and Dundas Formations. The WNW trending dolerite dyke swarm, however, which is present throughout the Thule basin (K-Ar age of $676 \pm 25$, Dawes et al., 1973) is not affected by this faulting. The relationship of faulting to older NNE to NE dykes is not known.

\section{Economic geology}

Pyrite, chalcopyrite and sphalerite are present in rusty dolomites and shales of the Dundas Formation in Steensby Land where dolerite sills are prominent. High sulphide concentrations occur in small lodes in the dolomites and in thin veins in both sediments and dolerite. Copper and sulphur staining is present in the shales. 
Malachite occurs in sandstones of the upper part of the Wolstenholme Formation in Olrik Fjord. One bright green patch several metres across occurs in an intensely faulted area and here malachite is richly disseminated in the sandstone.

Magnetite is not uncommon in the gneisses and also occurs in cross-cutting pegmatites. At Magnetitbugt, at the top of the sea cliff, it occurs in iron-rich veins and in layers within the gneiss. The magnetite rocks are commonly schists containing amphibole and quartz but some fine-grained, homogeneous, jet black magnetite rocks also occur. Banded ironstone composed of thin magnetite and quartz bands (Bøggild, 1953; Davies et al., 1963) was found only in drift.

llmenite-rich river sands occur at North Star Bugt (Ghisler \& Thomsen, 1971). Black sands are common in places at the coast in southern Steensby Land and samples containing extremely high heavy mineral concentrations (mainly ilmenite) were collected around Moriussaq. Source rocks are almost certainly the nearby and prominent dolerite sills.

Grey to pink agates occur in volcanic rocks in the lower part of the Wolstenholme Formation on Northumberland $\varnothing$ and at Siorapaluk in Prudhoe Land. Soapstone suitable for carving exists at several localities along the coast between Kap Atholl and Parker Snow Bugt.

\section{References}

Bøggild, O. B. 1953: The mineralogy of Greenland. Meddr. Grønland 149, 3, 442 pp.

Davies, W. E., Krinsley, D. B. \& Nicol, A. H. 1963: Geology of the North Star Bugt area, Northwest Greenland. Meddr Grфnland 162,12, $68 \mathrm{pp}$.

Dawes, P. R. 1972: Precambrian crystalline rocks and younger sediments of the Thule district, North Greenland. Rapp. Grønlands geol. Unders. 45, 10-15.

Dawes, P. R., Rex, D. C. \& Jepsen, H. F. 1973: K/Ar whole rock ages of dolerites from the Thule district, western North Greenland. Rapp. Gronlands geol. Unders. 55, 61-66.

Ghisler, M. \& Thomsen, B. 1971: The possibility of ilmenite placers in the Thule district, North Greenland. Rapp. Grфnlands geol. Unders. 43, 15 pp.

\section{Late Precambrian trace fossils from the Thule Group, western North Greenland}

\section{Peter R. Dawes and Richard G. Bromley}

The general 'unfossiliferous' nature of the thick, unmetamorphosed sediments of the Thule Group has been recognised since the last century. During field work in 1971 and 1974 a search was made by $P$. R. D. for organic remains but the only fossils encountered were stromatolites in some calcareous rocks and the trace fossils described here from thin bedded sandstones. Isotopic age dating of dolerites intruding the Thule Group shows that the Wolstenholme and Dundas Formations are of late Precambrian age and suggests that the younger Narssârssuk Formation is of similar age (Dawes et al., 1973). 